\title{
Uncommon skin cancer: pleomorphic dermal sarcoma
}

\author{
Sonia Rupal Sharma, ${ }^{1}$ George Meligonis, ${ }^{2}$ Pamela Todd ${ }^{1}$
}

Department of Dermatology, Addenbrooke's Hospital, Cambridge, UK

${ }^{2}$ Addenbrooke's Hospital, Cambridge, UK

\section{Correspondence to}

Dr Sonia Rupal Sharma, soniarupal.sharma@nhs.net

Accepted 9 February 2018

\section{DESCRIPTIONS}

An 86-year-old man presented to the dermatology clinic with a 10 -week history of lesion on the vertex of his scalp. This had been intermittently crusting and bleeding but was non-tender and not enlarging. The patient had a background of two previous squamous cell skin carcinomas of his right shoulder and left ear. With regards to his sun exposure, he had previously served in the armed forces and had been posted to hot countries. On physical examination there was a $9 \times 13 \mathrm{~mm}$ raised lesion with an overlying crust and rolled edges on the scalp vertex (see figure 1A,B). There was no evidence of cervical lymphadenopathy. Clinical suspicion was that of a keratoacanthoma or squamous cell carcinoma, given the patient's background. A $4 \mathrm{~mm}$ cutaneous punch biopsy was organised on the fasttrack pathway.

Histological analysis of the scalp lesion revealed a highly infiltrative tumour composed of small clusters of atypical plump spindle cells. The deeper aspect was composed of epithelioid cells with large, pleomorphic nuclei. There were mitoses present within the tumour, including atypical forms. There was no evidence of perineural or lymphovascular invasion. The tumour invaded the subcutaneous adipose tissue with a maximum depth of $4.5 \mathrm{~mm}$. The malignant cells showed weak to moderate positive immunostaining for smooth muscle actin and did not stain for AE1/AE3, S-100, desmin, CD31, CD34 or p63 (see figures 2 and 3).

The clinical, morphological and immunophenotype was in keeping with a pleomorphic dermal sarcoma (PDS). The patient was reviewed in clinic and the results discussed. Subsequent excision biopsy was performed with an overlying skin graft under the plastic surgery team with additional findings of actinic keratosis on histology. Our patient is currently awaiting further review.

PDS are rare and not well documented in the literature. They are thought to be closely related to atypical fibroxanthomas (AFX), sharing similar

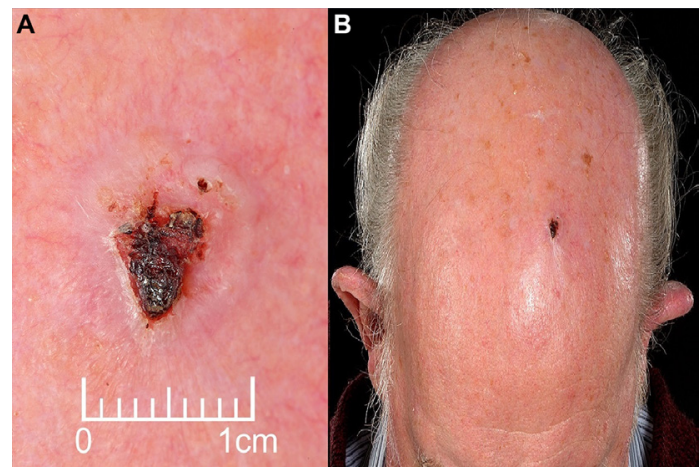

Figure $1 \quad(A, B)$ Close-up of the scalp lesion.

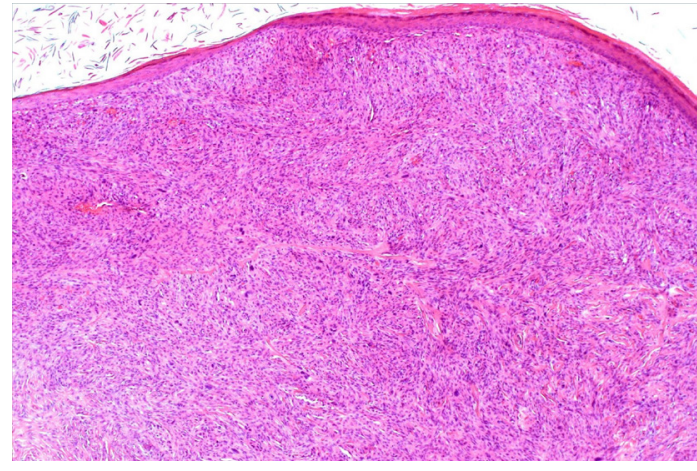

Figure 2 An area of the pleomorphic dermal sarcoma in the dermis (H\&E 40X).

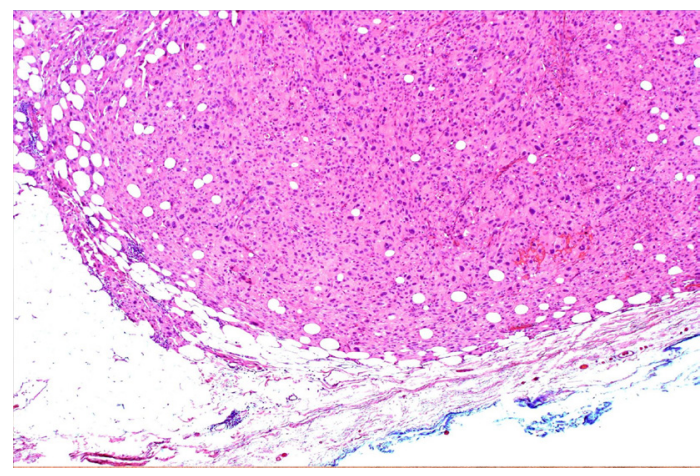

Figure 3 A deeper area of the pleomorphic dermal sarcoma invading the subcutis (H\&E 40x).

clinical, histological and immunophenotypical features. Clinically, both AFX and PDS affect elderly males on sun-damaged skin, with a strong predilection for the scalp. ${ }^{1}$ They typically have a rapid growth and ulcerate and bleed. Histologically, AFX are well-circumscribed growths, confined to the dermis. They contain pleomorphic, epithelioid, spindle and multinucleated tumour giant cells. ${ }^{1}$ PDS, however, display additional features such as infiltrative growth, invasion of the subcutis, tumour necrosis as well as lymphovascular invasion, suggesting that they may have a more aggressive course than AFX. Although a rare skin cancer and

\section{Learning points}

- Pleomorphic dermal sarcoma and atypical fibroxanthomas are closely related and likely part of the same disease spectrum.

- Although a rare cancer, it is important not to miss this diagnosis and follow-up patients due to their potential metastatic risk. 


\section{Images in...}

their metastatic potential estimated at $<5 \%$, it is important to not miss this diagnosis. ${ }^{2}$

Contributors SRS: clinical case management, literature review and writing of case report. GM: review of the histopathology and clinicopathological correlation. PT: clinical case management and case report finalisation.

Competing interests None declared.

Patient consent Obtained.

Provenance and peer review Not commissioned; externally peer reviewed. (c) BMJ Publishing Group Ltd (unless otherwise stated in the text of the article) 2018. All rights reserved. No commercial use is permitted unless otherwise expressly granted.

\section{REFERENCES}

1 Miller K, Goodlad JR, Brenn T. Pleomorphic dermal sarcoma: adverse histologic features predict aggressive behavior and allow distinction from atypical fibroxanthoma. Am J Surg Pathol 2012:36:1317-26.

2 Tardío JC, Pinedo F, Aramburu JA, et al. Pleomorphic dermal sarcoma: a more aggressive neoplasm than previously estimated. J Cutan Pathol 2016;43:101-12.

Copyright 2018 BMJ Publishing Group. All rights reserved. For permission to reuse any of this content visit

http://group.bmj.com/group/rights-licensing/permissions.

BMJ Case Report Fellows may re-use this article for personal use and teaching without any further permission.

Become a Fellow of BMJ Case Reports today and you can:

- Submit as many cases as you like

- Enjoy fast sympathetic peer review and rapid publication of accepted articles

Access all the published articles

Re-use any of the published material for personal use and teaching without further permission

For information on Institutional Fellowships contact consortiasales@bmjgroup.com

Visit casereports.bmj.com for more articles like this and to become a Fellow 